\title{
Substrate Directed Regioselective Monobromination of Aralkyl Ketones Using $N$-Bromosuccinimide Catalysed by Active Aluminium Oxide: $\alpha$-Bromination versus Ring Bromination
}

\author{
Reddy Bodireddy Mohan, G. Trivikram Reddy, and N. C. Gangi Reddy \\ Department of Chemistry, School of Physical Sciences, Yogi Vemana University, Kadapa, Andhra Pradesh 516003 , India \\ Correspondence should be addressed to N. C. Gangi Reddy; ncgreddy@yogivemanauniversity.ac.in
}

Received 23 November 2013; Accepted 24 December 2013; Published 4 March 2014

Academic Editors: M. D’Auria, M. Parra, J. Wu, and N. Zanatta

Copyright (c) 2014 Reddy Bodireddy Mohan et al. This is an open access article distributed under the Creative Commons Attribution License, which permits unrestricted use, distribution, and reproduction in any medium, provided the original work is properly cited.

\begin{abstract}
Bromination of aralkyl ketones using $\mathrm{N}$-bromosuccinimide in presence of active $\mathrm{Al}_{2} \mathrm{O}_{3}$ provided either $\alpha$-monobrominated products in methanol at reflux or mononuclear brominated products in acetonitrile at reflux temperature with excellent isolated yields depending on the nature of substrate employed. The $\alpha$-bromination was an exclusive process when aralkyl ketones containing moderate activating/deactivating groups were subjected to bromination under acidic $\mathrm{Al}_{2} \mathrm{O}_{3}$ conditions in methanol at reflux while nuclear functionalization was predominant when aralkyl ketones containing high activating groups were utilized for bromination in presence of neutral $\mathrm{Al}_{2} \mathrm{O}_{3}$ conditions in acetonitrile at reflux temperature. In addition, easy isolation of products, use of inexpensive catalyst, short reaction time (10-20 min), and safe operational practice are the major benefits in the present protocol.
\end{abstract}

\section{Introduction}

Nowadays, researchers are focusing on the development of more acceptable bromination protocols to accomplish increasing demands for "organohalogen" chemistry and to achieve higher efficiency and selectivity of the bromination reactions which include $\alpha$-bromination and nuclear bromination. The resulting $\alpha$-brominated or nuclear brominated products acquired wide range of utility in organic synthesis [1-3]. Nuclear brominated ketones are found to be useful intermediates in $\mathrm{C}-\mathrm{C}$ coupling reactions, as precursors to organometallic species and in nucleophilic substitutions.

It is well known that use of molecular bromine [4] as a basic electrophilic brominating reagent has several drawbacks. Alternative reagents were reported in the literature, for example, cupric bromide [5], dioxane dibromide [6], tetrabutyl ammonium tribromide [7], $\mathrm{H}_{2} \mathrm{O}_{2}-\mathrm{HBr}$ [8], bromodimethyl sulfoniumbromide [9], ethylene bis $(\mathrm{N}$-methyl imidazolium) ditribromide [10], trihaloisocyanuric acids [11], pyridinium bromochromate [12], and $\mathrm{NH}_{4} \mathrm{Br}$-oxone [13]. In addition, a popular and superior brominating agent such as $N$-bromosuccinimide [14] was utilized for $\alpha$-bromination of carbonyl compounds using a radical initiator such as azobisisobutyronitrile (AIBN) or dibenzoyl peroxide (BPO) [15] and, later, it has been demonstrated that the reactivity of NBS could be modulated with ionic liquids [16], photochemical energy [17]; sonochemical energy [18], solvent free reaction conditions (SFRC) [19] and various catalysts such as $\mathrm{Mg}\left(\mathrm{ClO}_{4}\right)_{2}$ [20], $\mathrm{NH}_{4} \mathrm{OAc}$ [21], amberlyst-15 [22], silica supported $\mathrm{NaHCO}_{3}$ [23], sulfonic acid functionalized silica [24], $\mathrm{FeCl}_{3}$ [25], montmorillonite-K10 [26], and Silica gel [27]. NBS also is utilized for ring or nuclear bromination using various catalysts such as $\mathrm{H}_{2} \mathrm{SO}_{4}-\mathrm{CF}_{3} \mathrm{CO}_{2} \mathrm{H}$ [28], p-toluenesulfonic acid [29], dibromodimethylhydantoin in aqueous base [30], amberlyst [31], and HZSM-5 [32].

It is well recognized that solids play a significant role in the development of cleaner technologies through their abilities to act as catalysts, support reagents, entrain byproducts, and influence product selectivity, and several books on the applications of solids in organic synthesis have appeared [33-35]. However, the catalysts and any accompanying reagent used along with $\mathrm{N}$-bromosuccinimide should be easily available to develop simple and efficient bromination procedure. Alumina $\left(\mathrm{Al}_{2} \mathrm{O}_{3}\right)$ has been used as a catalyst [36] 


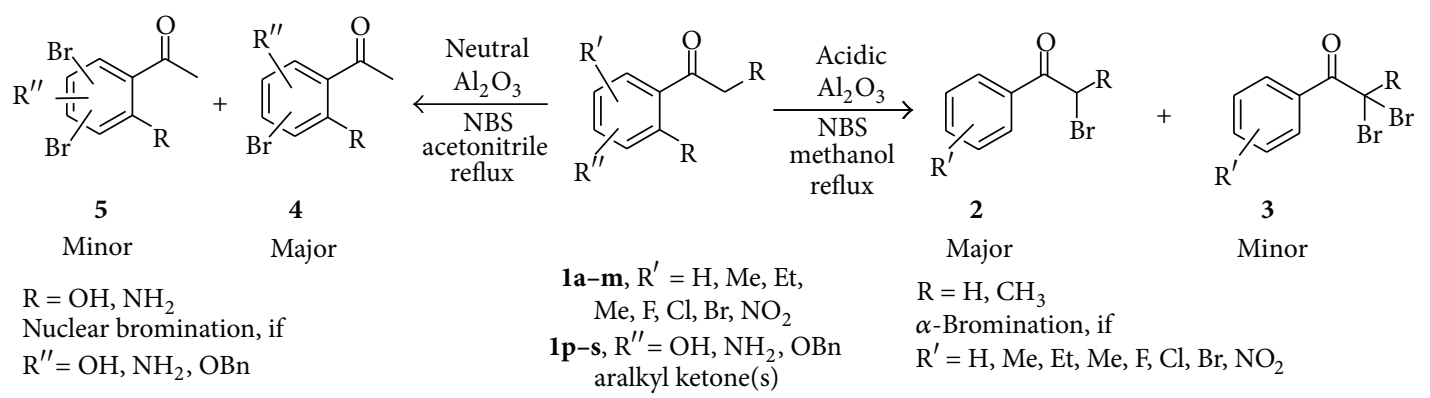

SCHEME 1: Substrate directed regioselective synthesis of monobrominated aralkyl ketones.

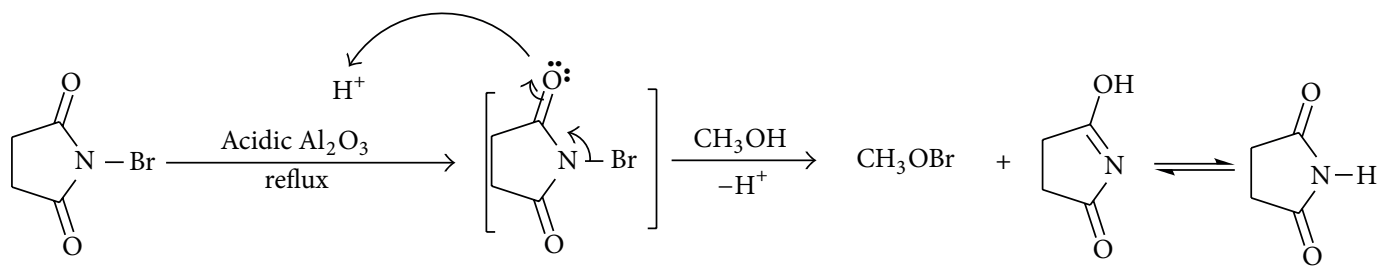

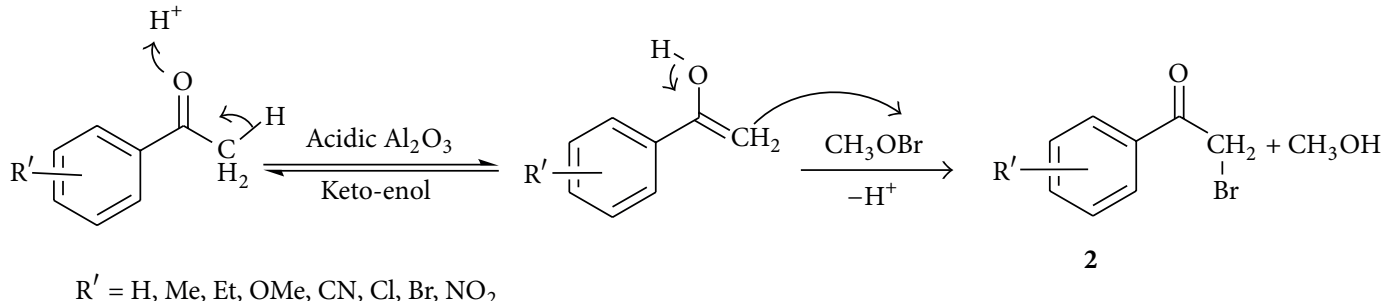

SCHEME 2: Plausible mechanism for $\alpha$-bromination.

in a wide variety of industrial processes for many years [37]. But Alumina $\left(\mathrm{Al}_{2} \mathrm{O}_{3}\right)$ has limited catalytic applications in synthetic organic chemistry [38]. However, on deep investigation it is found that aralkyl ketones with moderate activating/moderate or high deactivating groups undergo exclusively $\alpha$-bromination in the presence of acidic alumina in methanol, while substrates with high activating groups undergo nuclear bromination predominantly in the presence of neutral alumina in acetonitrile at reflux temperature, as shown in Scheme 1

Plausible mechanism for bromination of aralkyl ketones containing moderate activating/deactivating groups may be involved in the exclusive formation of enolic form of ketone in presence of acidic $\mathrm{Al}_{2} \mathrm{O}_{3}$ aids predominant formation of $\alpha$-brominated product (2). In addition, acidic $\mathrm{Al}_{2} \mathrm{O}_{3}$ may enhance the rate of release of bromonium ion from NBS and subsequent capture of bromonium ion by nucleophilic solvent such as methanol leads to rapid completion of the reaction (10-15 $\mathrm{min}$ ) as shown in Scheme 2.

In contrast, aralkylketones containing high electron donating groups may be susceptible to rapid activation of the aromatic ring of substrate and rapid release of bromonium ion from NBS via surface interaction with neutral $\mathrm{Al}_{2} \mathrm{O}_{3}$ which leads to exclusive formation of nuclear brominated product (4) in acetonitrile based on substrate employed and the catalyst may assist in abstracting the proton during the course of bromination as shown in Scheme 3.

\section{Results and Discussion}

Initially, two types of substrates were selected for optimization of reaction conditions using $N$-bromosuccinimide in presence of either acidic or neutral $\mathrm{Al}_{2} \mathrm{O}_{3}$. Accordingly, acetophenone and $4^{\prime}$-hydroxy acetophenone were utilized for the evaluation of reaction conditions such as effect of solvent, temperature, catalyst, and catalyst load and the obtained results are discussed below.

The effect of catalyst on the course of bromination of acetophenone was studied and the obtained results were summarized in Table 1 . It was observed that acidic $\mathrm{Al}_{2} \mathrm{O}_{3}$ (entry 3, Table 1) provided better yields of desired $\alpha$-brominated product ( $2 \mathbf{a}$ ) compared to neutral $\mathrm{Al}_{2} \mathrm{O}_{3}$ (entry 5) in methanol at reflux temperature. It might be attributed that acidic nature of $\mathrm{Al}_{2} \mathrm{O}_{3}$ may enhance the formation of enol form of substrate and subsequent bromination also. In addition, acidic nature of catalyst might boost the rate of release of bromonium ion from $N$-bromosuccinimide followed by the capture of bromonium ion by nucleophilic solvent such as methanol. Reuse of acidic $\mathrm{Al}_{2} \mathrm{O}_{3}$ provided $89 \%, 86 \%, 81 \%$, and $72 \%$ yields of product (2a) for first, second, third, and fourth time, respectively.

We also studied the effect of acidic $\mathrm{Al}_{2} \mathrm{O}_{3}$ catalyst load on the course of $\alpha$-bromination. Towards this direction, $5 \%, 10 \%$, and $15 \%$ of catalyst (w/w) was applied and the obtained yields of product $\mathbf{2 a}$ were $71 \%, 89 \%$, and $78 \%$, respectively. The study 

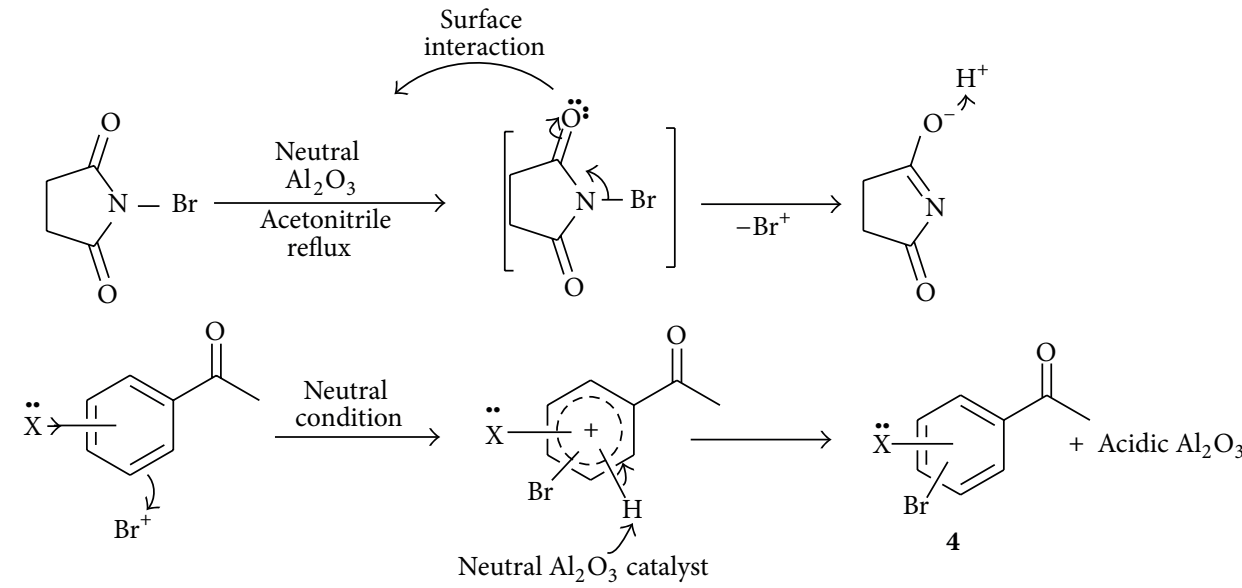

$\mathrm{X}=\mathrm{R}^{\prime \prime}=\mathrm{OH}, \mathrm{NH}_{2}, \mathrm{OMe}, \mathrm{OBn}$

Scheme 3: Plausible mechanism for nuclear functionalization.

TABLE 1: Exploring of catalyst and other reaction conditions for $\alpha$-bromination of $1 \mathbf{a}$ using NBS ${ }^{\mathrm{a}}$.

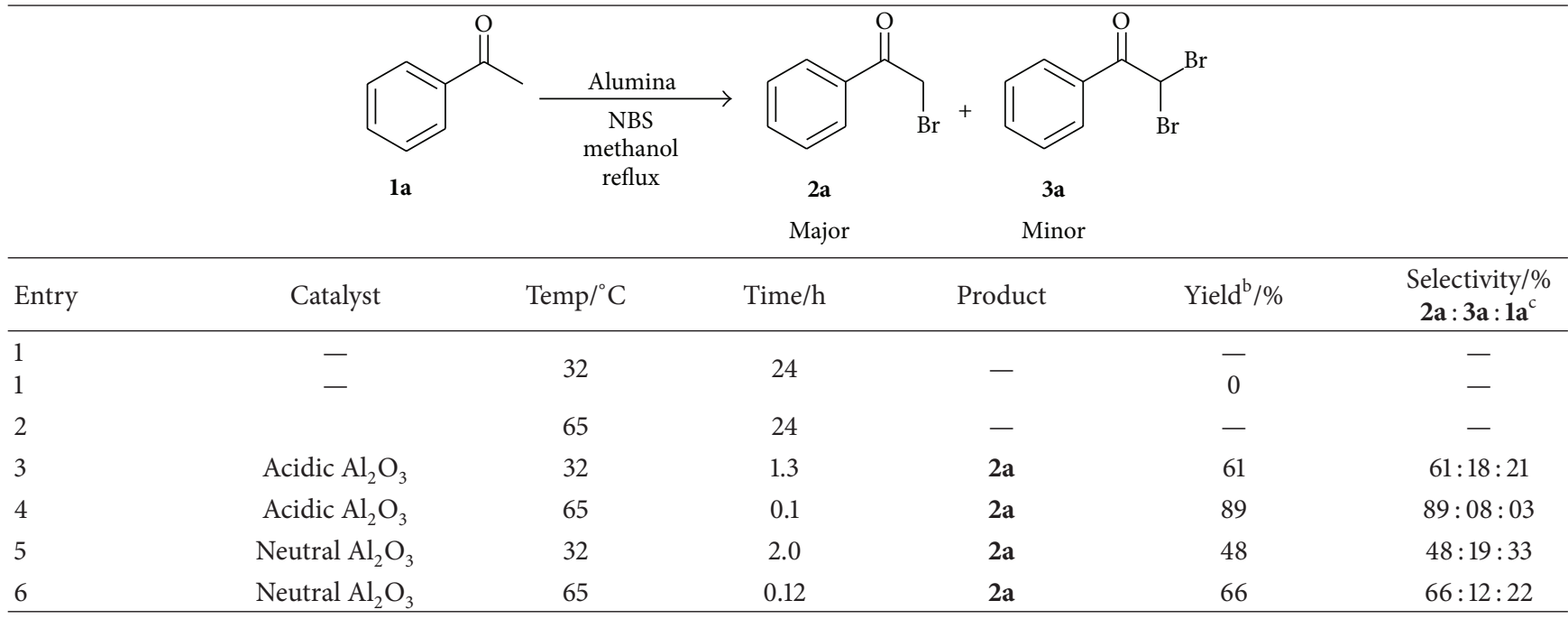

${ }^{a}$ Reaction conditions: acetophenone $\mathbf{1 a}(10 \mathrm{mmol}), \mathrm{N}$-bromosuccinimide $(12 \mathrm{mmol}), 10 \%$ (w/w) catalyst, and methanol (20 vol) at reflux temperature.

${ }^{\mathrm{b}}$ Isolated yield of product $\mathbf{2 a}$.

${ }^{\mathrm{c}}$ Unreacted acetophenone.

revealed that $10 \%(\mathrm{w} / \mathrm{w})$ of acidic $\mathrm{Al}_{2} \mathrm{O}_{3}$ is optimum for better isolated yield of product $\mathbf{2 a}$.

Later, we focused on the optimization of other reaction parameters such as effect of solvent in presence of $10 \%$ of acidic $\mathrm{Al}_{2} \mathrm{O}_{3}$. Consequently, the effect of solvents on the course of $\alpha$-bromination was studied using different types of solvents and the obtained results were presented in Table 2. For example $\mathrm{MeOH}, \mathrm{EtOH}, \mathrm{H}_{2} \mathrm{O}, \mathrm{CH}_{3} \mathrm{CN}$, THF, $\mathrm{CH}_{2} \mathrm{Cl}_{2}$, are $\mathrm{CHCl}_{3}$ were provided $89 \%, 74 \%, 15 \%, 51 \%, 56 \%, 44 \%$, $55 \%$, and $48 \%$ yields of desired product $2 \mathrm{a}$, respectively. Interestingly, a high yield (89\%) of product $\mathbf{2 a}$ was obtained when methanol was used as solvent (entry 1, Table 1).

As evident from the literature [26], portion wise addition of $\mathrm{N}$-bromosuccinimide caused to control the release of bromonium ion and it provided improved yields of $\alpha$ brominated product (2a). The same was implemented in the present investigation and $\mathrm{N}$-bromosuccinimide was added portion wise (10 portions). As a consequence, the isolated yield of product $\mathbf{2 a}$ was improved up to $89 \%$ compared to one time NBS addition, which provided lower yield (74\%) of product $\mathbf{2 a}$.

With the help of optimized reaction conditions, further scope and generality of the $\alpha$-bromination was tested by utilizing a series of aralkyl ketones containing moderate activating/deactivating groups and highly deactivating groups in presence of acidic $\mathrm{Al}_{2} \mathrm{O}_{3}$ in methanol and the obtained results were presented in Table 3 . It was found that presence of moderate activating and deactivating groups on phenyl ring of aralkylketones favors the $\alpha$-bromination (entries 1-10 and 11, Table 3 and entries 1 and 2, Table 4) with excellent isolated yields of desired product(s), whilst presence of highly deactivating groups provided lower yields of product (entries 12 and 
TABLE 2: Effect of solvent on $\alpha$-bromination of acetophenone ${ }^{\mathrm{a}}$.

\begin{tabular}{lcccc}
\hline Entry & Solvent & Time/min & Product & Yield $^{\mathrm{b}} \%$ \\
\hline 1 & $\mathrm{MeOH}$ & 10 & $\mathbf{2 a}$ & 89 \\
2 & $\mathrm{EtOH}$ & 40 & $\mathbf{2 a}$ & 74 \\
3 & $\mathrm{H}_{2} \mathrm{O}$ & $24 \mathrm{hrs}$ & $\mathbf{2 a}$ & 15 \\
4 & $\mathrm{CH}_{3} \mathrm{CN}$ & 60 & $\mathbf{2 a}$ & 51 \\
${ }^{\mathrm{c}} 5$ & ${ }^{\mathrm{d}} \mathrm{Ether}$ & 30 & $\mathbf{2 a}$ & 56 \\
6 & ${ }^{\mathrm{d}} \mathrm{THF}$ & 65 & $\mathbf{2 a}$ & 44 \\
7 & $\mathrm{CH}_{2} \mathrm{Cl}_{2}$ & 180 & $\mathbf{2 a}$ & 55 \\
8 & $\mathrm{CHCl}_{3}$ & 120 & 2a & 48 \\
\hline
\end{tabular}

${ }^{a}$ Reaction conditions: acetophenone $\mathbf{1 a}(10 \mathrm{mmol}), \mathrm{N}$-bromosuccinimide $(12 \mathrm{mmol}), 10 \%(\mathrm{w} / \mathrm{w})$ acidic $\mathrm{Al}_{2} \mathrm{O}_{3}$, and solvent $(20 \mathrm{vol})$ at reflux temperature.

${ }^{\mathrm{b}}$ Isolated yield.

${ }^{\mathrm{c}}$ Reaction was conducted at $32^{\circ} \mathrm{C}$.

${ }^{\mathrm{d}}$ Freshly distilled ether and THF were used (peroxide free).

13, Table 3). Fascinatingly, $\alpha$-brominated product (2k) was formed exclusively even though $4^{\prime}$-methoxyacetophenone contains high activating group (-OMe) (entry 11, Table 3 ).

Acenaphthones(s) were subjected to bromination using $N$-bromosuccinimide in presence of acidic $\mathrm{Al}_{2} \mathrm{O}_{3}$ in methanol at reflux temperature and they provided respective $\alpha$ brominated products ( $\mathbf{2 n}$ and $\mathbf{2 0}$, entries 1 and 2, Table 4) exclusively. The obtained results were presented in Table 4 .

In continuation of our agenda to explore the effect of Alumina catalyst on different types of substrates, we focused on the effect of neutral alumina on the course of bromination. As a result, we selected $4^{\prime}$-hydroxy acetophenone (1p) as model substrate and the reaction conditions were optimized with respect to it. The obtained results were presented in Table 5.

When we applied neutral $\mathrm{Al}_{2} \mathrm{O}_{3}$ (entry 6, Table 5) for bromination reaction of $4{ }^{\prime}$-hydroxy acetophenone $(\mathbf{1 p})$, good yield of nuclear brominated product (4a) was obtained compared to acidic $\mathrm{Al}_{2} \mathrm{O}_{3}$ (entry 4, Table 5) in methanol at reflux temperature. It may be attributed that acidic $\mathrm{Al}_{2} \mathrm{O}_{3}$ might deactivate the electron donating efficiency of high activating groups. In contrast, neutral $\mathrm{Al}_{2} \mathrm{O}_{3}$ might facilitate the activation of the aromatic ring of aralkyl ketone as well as the rate of formation of bromonium ion from NBS via surface interaction with reactants.

To improve the yields of product $\mathbf{4 a}$ further, we have studied the effect of solvent on the course of bromination and the obtained results were depicted in Table 6. Solvents such as $\mathrm{MeOH}, \mathrm{EtOH}, \mathrm{H}_{2} \mathrm{O}, \mathrm{CH}_{3} \mathrm{CN}$, THF, $\mathrm{CH}_{2} \mathrm{Cl}_{2}$, and $\mathrm{CHCl}_{3}$ were provided $86 \%, 61 \%, 22 \%, 94 \%, 48 \%, 40 \%, 30 \%$, and $34 \%$ yields of desired product $\mathbf{4 a}$, respectively. The solvent study disclosed that acetonitrile is the best to obtain maximum yield (94\%) of the product $\mathbf{4 a}$ (entry 4 , Table 6 ) compared to methanol (86\%) (entry 1, Table 6). Reuse of catalyst provided $94 \%, 89 \%, 80 \%$, and $74 \%$ yields of product (4a) for first, second, third, and fourth time, respectively.

It was observed that portion wise (10 portions) addition of $N$-bromosuccinimide provided improved yield (94\%) of product 4 a compared to one-time addition of $\mathrm{N}$-bromosuccinimide which provided lower yield (65\%) of product 4a. The study revealed that the portion wise addition of NBS resulted in improved yields of product $\mathbf{4 a}$.

With the help of optimized reaction conditions further generality of the nuclear bromination was tested with a variety of substrates $(\mathbf{1} \mathbf{p}-\mathbf{r})$ containing high activating groups in presence of neutral $\mathrm{Al}_{2} \mathrm{O}_{3}$ in acetonitrile at reflux temperature and the obtained results were summarized in Table 7 . It was found that neutral $\mathrm{Al}_{2} \mathrm{O}_{3}$ provided good yields of nuclear monobrominated products (entries 1-5, Table 7).

Excess use of $N$-bromosuccinimide $(24 \mathrm{mmol}$ ) provided excellent yields of nuclear dibrominated products $\mathbf{5 a}$ and $\mathbf{5 b}$ (entries 6 and 7, Table 7). The $4^{\prime}$-methoxy acetophenone (1k) in acetonitrile solvent in presence of neutral $\mathrm{Al}_{2} \mathrm{O}_{3}$ provided exclusively nuclear brominated product $5 \mathbf{e}$ instead of $\mathbf{2 k}$.

Encouraged by the above fruitful results, we attempted to prepare 1-(3,5-bis(benzyloxy) phenyl)-2-bromoethanone (2p), a key $\alpha$-brominated intermediate product in the synthesis of terbutaline sulphate drug starting from the substrate, $3^{\prime}, 5^{\prime}$-dibenzyloxy acetophenone (1s).

Interestingly, we obtained $95-98 \%$ yields of mononuclear brominated product of 1-(3,5-bis(benzyloxy)-4-bromophenyl)ethanone (4f) exclusively both in presence of acidic $\mathrm{Al}_{2} \mathrm{O}_{3}$ in methanol and neutral $\mathrm{Al}_{2} \mathrm{O}_{3}$ in acetonitrile as depicted in Scheme 4.

\section{Conclusion}

In summation, we demonstrated that using $\mathrm{Al}_{2} \mathrm{O}_{3}$ as catalyst, monobromination of various aralkyl ketones was achieved in high yield with high substrate directed regioselectivity $(\alpha-$ bromination versus nuclear bromination) using NBS. The $\alpha$ bromination was the exclusive process when aralkyl ketones containing moderate activating/deactivating groups were subjected to bromination under acidic $\mathrm{Al}_{2} \mathrm{O}_{3}$ conditions in methanol at reflux while nuclear functionalization was predominant when aralkyl ketones containing high activating groups were utilized for bromination in presence of neutral $\mathrm{Al}_{2} \mathrm{O}_{3}$ conditions in acetonitrile at reflux temperature. Thus, our new protocol offers safe operational procedure, short reaction time (10-20 $\mathrm{min}$ ), and use of inexpensive and recyclable catalyst for 3 times without loss of activity.

\section{Experimental}

4.1. General. All chemicals used were reagent grade and were used as received without further purification. Ketones were purchased from Acros, Merck, and SD Fine Chemicals Ltd., Mumbai, India and Avra Laboratories Ltd., Hyderabad, India. $N$-bromosuccinimide was purchased from Merck. Methanol (99.0\%) was purchased from SD Fine Chemicals Ltd. EtOAc was purchased from Merck. The double distilled millipore deionized water was used for work up. Melting points were determined in open capillaries on REMI melting point apparatus and were uncorrected. ${ }^{1} \mathrm{H}$ NMR spectra were recorded on a Varian $400 \mathrm{MHz}$. Chemical shifts were expressed in parts per million (ppm). Splitting patterns describe apparent multiplicities and are designated as $\mathrm{s}$ (singlet), $\mathrm{d}$ (doublet), $\mathrm{t}$ (triplet), q (quartet), m (multiplet), or br (broad). Mass 
TABLE 3: $\alpha$-Bromination of acetophenone derivative(s) containing moderate activating/deactivating or high deactivating groups ${ }^{\mathrm{a}}$.

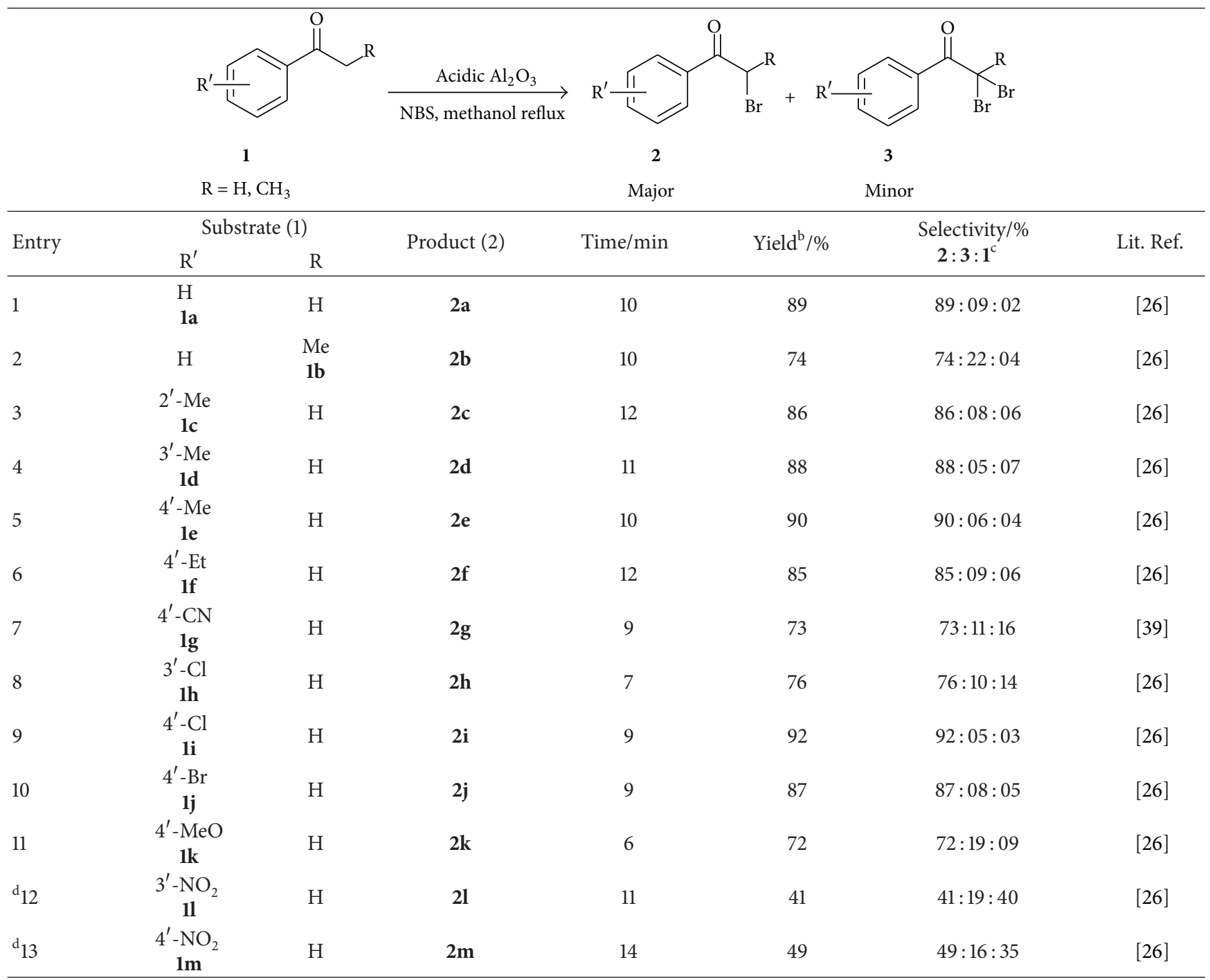

${ }^{a}$ Reaction conditions: $\mathbf{1}(10 \mathrm{mmol}), \mathrm{N}$-bromosuccinimide $(12 \mathrm{mmol})$, and $10 \%(\mathrm{w} / \mathrm{w})$ acidic $\mathrm{Al}_{2} \mathrm{O}_{3}$ in methanol $(20 \mathrm{~mL})$ at reflux temperature.

${ }^{\mathrm{b}}$ Isolated yield.

${ }^{\mathrm{c}}$ Unreacted substrate.

$\mathrm{d}_{5 \%}$ acidic $\mathrm{Al}_{2} \mathrm{O}_{3}$ was applied.

spectra (MS) are acquired on agilent, model-6410, Triple Quad LC MS. Thin-layer chromatography was performed on $0.25 \mathrm{~mm}$ Merck silica gel plates (60F-254) and visualized with UV light. Column chromatography was performed on silica gel (finer than 200 mesh, Merck).

\subsection{Active $\mathrm{Al}_{2} \mathrm{O}_{3}$ Catalyst Specification(s)}

4.2.1. Acidic $\mathrm{Al}_{2} \mathrm{O}_{3}$. Acidic $\mathrm{Al}_{2} \mathrm{O}_{3}$ is commercially available (Merck made) and has the following characteristics (i) White crystalline solid, (ii) $\mathrm{pH}$ value ( $10 \%$ aqueous suspension) is 4-5; (iii) active according to Brockmann for column chromatography.

4.2.2. Neutral $\mathrm{Al}_{2} \mathrm{O}_{3}$. Neutral $\mathrm{Al}_{2} \mathrm{O}_{3}$ is commercially available (Fisher made) and has the following characteristics (i) White crystalline solid, (ii) $\mathrm{pH}$ value (10\% aqueous suspension) is 6.8-7.8; (iii) active according to Brockmann for column chromatography.

4.3. General Experimental Procedure for $\alpha$-Bromination. In a $100 \mathrm{~mL}$ RB flask fitted with condenser, the aralkylketone 1a (10 mmol), $10 \%$ (w/w) active $\mathrm{Al}_{2} \mathrm{O}_{3}$ catalyst, and methanol $(20 \mathrm{vol})$ were added. The temperature of the reaction mass was raised to reflux. Then, $N$-bromosuccinimide $(12 \mathrm{mmol})$ was added portion wise (10 portions). After completion of the reaction, as monitored by TLC (mobile phase is a mixture of $5 \mathrm{~mL}$-hexane and 3 drops of EtOAc; Caution: there is need to run TLC for 3-5 times for clear distinction between mono versus dibrominated products), the reaction mixture was filtered to collect the catalyst and the solvent was removed under reduced pressure. Water $(100 \mathrm{~mL})$ was added to the reaction mass and the formed $\alpha$-brominated product was extracted thrice with EtOAc $(3 \times 50 \mathrm{~mL})$. Layers 
TABLE 4: $\alpha$-Bromination of acenaphthone $\mathrm{a}^{\mathrm{a}}$.

(26]

${ }^{a}$ Reaction conditions: acenaphthone $\mathbf{1}(10 \mathrm{mmol}), \mathrm{N}$-bromosuccinimide $(12 \mathrm{mmol})$, and $10 \%$ acidic $\mathrm{Al}_{2} \mathrm{O}_{3}$ in methanol $(20 \mathrm{~mL})$ at reflux temperature.

${ }^{\mathrm{b}}$ Isolated yield of desired product(s).

${ }^{\mathrm{c}}$ Unreacted substrate.

TABLE 5: Exploring of suitable catalyst for nuclear bromination ${ }^{\mathrm{a}}$.

Cntry
Catalyst

were separated and the organic layer was collected and then washed thrice with water $(3 \times 50 \mathrm{~mL})$. The organic layer was collected and dried over anhydrous $\mathrm{Na}_{2} \mathrm{SO}_{4}$ and the solvent was removed using rotary evaporator. Pure $\alpha$ brominated product (2a) was obtained from crude residue after purification by column chromatography over silica gel using a mixture of $\mathrm{n}$-hexane and EtOAc (99:1 ratio).

4.4. General Experimental Procedure for Nuclear Bromination. In a $100 \mathrm{~mL}$ RB flask fitted with condenser, the aralkylketone 
TABLE 6: Effect of solvent on nuclear bromination of $4^{\prime}$-Hydroxy acetophenone $(\mathbf{1 p})^{\mathrm{a}}$.

\begin{tabular}{lcccc}
\hline Entry & Solvent & Time/min & Product & Yield $^{\mathrm{b}} \%$ \\
\hline 1 & $\mathrm{MeOH}$ & 12 & $\mathbf{4 a}$ & 86 \\
2 & $\mathrm{EtOH}$ & 60 & $\mathbf{4 a}$ & 61 \\
3 & $\mathrm{H}_{2} \mathrm{O}$ & $24 \mathrm{hrs}$ & $\mathbf{4 a}$ & 22 \\
4 & $\mathrm{CH}_{3} \mathrm{CN}$ & 14 & $\mathbf{4 a}$ & 94 \\
${ }^{\mathrm{c}} 5$ & ${ }^{\mathrm{d}} \mathrm{Ether}$ & 45 & $\mathbf{4 a}$ & 48 \\
6 & ${ }^{\mathrm{d}} \mathrm{THF}$ & 75 & $\mathbf{4 a}$ & 40 \\
7 & $\mathrm{CH}_{2} \mathrm{Cl}_{2}$ & 150 & $\mathbf{4 a}$ & 30 \\
8 & $\mathrm{CHCl}_{3}$ & 90 & $\mathbf{4 a}$ & 34 \\
\hline
\end{tabular}

${ }^{a}$ Reaction conditions: 4'-hydroxy acetophenone $\mathbf{1 p}(10 \mathrm{mmol}), \quad N$ bromosuccinimide $(12 \mathrm{mmol}), 10 \%(\mathrm{w} / \mathrm{w})$ neutral $\mathrm{Al}_{2} \mathrm{O}_{3}$, and solvent $(20$ vol) at reflux temperature.

${ }^{\mathrm{b}}$ Isolated yield.

${ }^{c}$ Reaction was conducted at $32^{\circ} \mathrm{C}$.

${ }^{\mathrm{d}}$ Freshly distilled ether and THF were used (peroxide free).

$1 p(10 \mathrm{mmol}), 10 \%(\mathrm{w} / \mathrm{w})$ neutral $\mathrm{Al}_{2} \mathrm{O}_{3}$ catalyst, and acetonitrile $(20 \mathrm{vol})$ were added. The temperature of the reaction mass was raised to reflux. Then, $N$-bromosuccinimide $(12 \mathrm{mmol})$ was added portion wise (10 portions). After completion of the reaction, as monitored by TLC (mobile phase is a mixture of $5 \mathrm{~mL} \mathrm{n}$-hexane and 3 drops of EtOAc; caution: there is need to run TLC for 3-5 times for clear distinction between mono- versus dibrominated products), the reaction mixture was filtered to collect the catalyst and the solvent was removed under vacuum. Water $(100 \mathrm{~mL})$ was added to the reaction mass and the formed nuclear brominated product was extracted thrice with EtOAc $(3 \times 50 \mathrm{~mL})$. Layers were separated and the organic layer was collected and it was washed thrice with water $(3 \times 50 \mathrm{~mL})$. The organic layer was collected and dried over anhydrous $\mathrm{Na}_{2} \mathrm{SO}_{4}$ and the solvent was removed using rotary evaporator. Pure nuclear brominated product (4a) was obtained from crude residue after purification by column chromatography over silica gel using a mixture of n-hexane and EtOAc (99:1 ratio).

\subsection{Physical and Spectral Characterization Data}

4.5.1. 2-Bromo-1-phenyl Ethanone (2a). Off-white solid, yield: $89 \%$; m.p. $48-50^{\circ} \mathrm{C}$; FT-IR $\left(\mathrm{KBr}, \mathrm{cm}^{-1}\right)$ : 3085.6, 2999.6, 1694.3, 1589.7, 1485.8, 1283.6, 1198.8, 811.8, 665.7, 548.1. ${ }^{1} \mathrm{H}-$ $\operatorname{NMR}\left(400 \mathrm{MHz}, \mathrm{CDCl}_{3}, \delta / \mathrm{ppm}\right): 8.00-8.10(2 \mathrm{H}, \mathrm{m}$, arom H), 7.43-7.78 (3H, m, arom H), $4.50\left(2 \mathrm{H}, \mathrm{s},-\mathrm{CH}_{2}\right)$. MS (ESI) $\mathrm{m} / z$ $199.05\left[\mathrm{M}^{+\bullet}+\mathrm{H},{ }^{79} \mathrm{Br}\right], 201.1\left[\mathrm{M}^{+\bullet}+\mathrm{H}+2,{ }^{81} \mathrm{Br}\right]$.

4.5.2. 2-Bromo-1-phenylpropan-1-one (2b). Colorless liquid, yield: $74 \%$; b.p. $247-251^{\circ} \mathrm{C}$; ${ }^{1} \mathrm{H}-\mathrm{NMR}\left(400 \mathrm{MHz}, \mathrm{CDCl}_{3}\right.$, $\delta / \mathrm{ppm}): 8.10(2 \mathrm{H}, \mathrm{d}, J=7.2 \mathrm{~Hz}$, arom $\mathrm{H}), 7.72-7.64(1 \mathrm{H}, \mathrm{m}$, arom $\mathrm{H}), 7.50-7.60(2 \mathrm{H}, \mathrm{m}$, arom $\mathrm{H}), 5.30(1 \mathrm{H}, \mathrm{q}, J=6.8 \mathrm{~Hz}$, alkyl H), $2.10\left(3 \mathrm{H}, \mathrm{d}, J=7.2 \mathrm{~Hz},-\mathrm{CH}_{3}\right)$; MS (ESI) $m / z 213.03$ $\left[\mathrm{M}^{+\bullet}+\mathrm{H},{ }^{79} \mathrm{Br}\right], 215.2\left[\mathrm{M}^{+\bullet}+\mathrm{H}+2,{ }^{81} \mathrm{Br}\right]$.

4.5.3. 2-Bromo-1-o-tolylethanone (2c). Colorless liquid, yield: 86\%; b.p. $81-83^{\circ} \mathrm{C}$; ${ }^{1} \mathrm{H}-\mathrm{NMR}\left(400 \mathrm{MHz}, \mathrm{CDCl}_{3}, \delta / \mathrm{ppm}\right): 8.10$
$(1 \mathrm{H}, \mathrm{d}, \operatorname{arom~} \mathrm{H}, J=8.0 \mathrm{~Hz}), 7.70(1 \mathrm{H}, \mathrm{t}, J=7.6 \mathrm{~Hz}$, arom $\mathrm{H})$, $7.40(1 \mathrm{H}, \mathrm{t}, J=7.2 \mathrm{~Hz}$, arom H), $7.10(1 \mathrm{H}, \mathrm{d}, J=8.0 \mathrm{~Hz}$, arom H), $4.50\left(2 \mathrm{H}, \mathrm{s},-\mathrm{CH}_{2}\right), 2.50\left(3 \mathrm{H}, \mathrm{s},-\mathrm{CH}_{3}\right)$; MS (ESI): $m / z 212.96$ $\left[\mathrm{M}^{+\bullet}+\mathrm{H},{ }^{79} \mathrm{Br}\right], 214.97\left[\mathrm{M}^{+\bullet}+\mathrm{H}+2,{ }^{81} \mathrm{Br}\right]$.

4.5.4. 2-Bromo-1-m-tolylethanone (2d). Colorless liquid, yield: $88 \%$; b.p. $234^{\circ} \mathrm{C} ;{ }^{1} \mathrm{H}-\mathrm{NMR}\left(400 \mathrm{MHz}, \mathrm{CDCl}_{3}, \delta / \mathrm{ppm}\right)$ : $7.83(1 \mathrm{H}, \mathrm{d}, J=8.0 \mathrm{~Hz}$, arom $\mathrm{H}), 7.58(1 \mathrm{H}, \mathrm{s}$, arom $\mathrm{H}), 7.35(1 \mathrm{H}$, $\mathrm{d}, J=7.6 \mathrm{~Hz}$, arom $\mathrm{H}), 7.10(1 \mathrm{H}, \mathrm{t}, J=7.2 \mathrm{~Hz}$, arom $\mathrm{H}), 4.60$ $\left(2 \mathrm{H}, \mathrm{s},-\mathrm{CH}_{2}\right), 2.48\left(3 \mathrm{H}, \mathrm{s},-\mathrm{CH}_{3}\right) ; \mathrm{MS}(\mathrm{ESI}): \mathrm{m} / z 213.15$ $\left[\mathrm{M}^{+\bullet}+\mathrm{H},{ }^{79} \mathrm{Br}\right], 215.1\left[\mathrm{M}^{+\bullet}+\mathrm{H}+2,{ }^{81} \mathrm{Br}\right]$.

4.5.5. 2-Bromo-1-p-tolylethanone (2e). Off-white solid, yield: 90\%, m.p. 51-53 ${ }^{\circ}$ C. ${ }^{1} \mathrm{H}-\mathrm{NMR}\left(400 \mathrm{MHz}, \mathrm{CDCl}_{3}, \delta / \mathrm{ppm}\right): 7.65$ $(2 \mathrm{H}, \mathrm{d}, J=7.6 \mathrm{~Hz}$, arom $\mathrm{H}), 7.00(2 \mathrm{H}, \mathrm{d}, J=7.2 \mathrm{~Hz}$, arom $\mathrm{H})$, $4.70\left(2 \mathrm{H}, \mathrm{s},-\mathrm{CH}_{2}\right), 2.54\left(3 \mathrm{H}, \mathrm{s},-\mathrm{CH}_{3}\right)$; MS (ESI): $m / z 212.89$ $\left[\mathrm{M}^{+\bullet}+\mathrm{H},{ }^{79} \mathrm{Br}\right], 214.81\left[\mathrm{M}^{+\bullet}+\mathrm{H}+2,{ }^{81} \mathrm{Br}\right]$.

4.5.6. 2-Bromo-1-(4-ethylphenyl)ethanone (2f). Colorless liquid, yield: $85 \%$; b.p. $288.5^{\circ} \mathrm{C} .{ }^{1} \mathrm{H}-\mathrm{NMR}\left(400 \mathrm{MHz}, \mathrm{CDCl}_{3}\right.$, $\delta / \mathrm{ppm}): 7.45(2 \mathrm{H}, \mathrm{d}, J=8.0 \mathrm{~Hz}$, arom $\mathrm{H}), 7.20(2 \mathrm{H}, \mathrm{d}, J=$ $7.6 \mathrm{~Hz}$, arom $\mathrm{H}), 4.60\left(2 \mathrm{H}, \mathrm{s},-\mathrm{CH}_{2}\right), 2.64(2 \mathrm{H}, \mathrm{q}, J=7.6 \mathrm{~Hz}$, $\left.-\mathrm{CH}_{2}\right), 1.54\left(3 \mathrm{H}, \mathrm{t}, J=6.8 \mathrm{~Hz},-\mathrm{CH}_{3}\right) ; \mathrm{MS}(\mathrm{ESI}): m / z 226.95$ $\left[\mathrm{M}^{+\bullet}+\mathrm{H},{ }^{79} \mathrm{Br}\right], 229.08\left[\mathrm{M}^{+\bullet}+\mathrm{H}+2,{ }^{81} \mathrm{Br}\right]$.

4.5.7. 4-(2-Bromoacetyl)benzonitrile (2g). Off-white solid, yield: $73 \%$, m.p. $90-92^{\circ} \mathrm{C} .{ }^{1} \mathrm{H}-\mathrm{NMR}\left(400 \mathrm{MHz}, \mathrm{CDCl}_{3}\right.$, $\delta / \mathrm{ppm}): 8.24(2 \mathrm{H}, \mathrm{d}, J=7.2 \mathrm{~Hz}$, arom H), $7.91(2 \mathrm{H}, \mathrm{d}, J=7.6 \mathrm{~Hz}$, arom $\mathrm{H}), 4.32\left(2 \mathrm{H}, \mathrm{s},-\mathrm{CH}_{2}\right)$; MS (ESI): $m / z 224.15\left[\mathrm{M}^{+\bullet}+\mathrm{H}\right.$, $\left.{ }^{79} \mathrm{Br}\right], 226.01\left[\mathrm{M}^{+\bullet}+\mathrm{H}+2,{ }^{81} \mathrm{Br}\right]$.

4.5.8. 2-Bromo-1-(3-chlorophenyl)ethanone (2h). Off-white solid, yield: $76 \%$; m.p. $39-42^{\circ} \mathrm{C} .{ }^{1} \mathrm{H}-\mathrm{NMR}\left(400 \mathrm{MHz}, \mathrm{CDCl}_{3}\right.$, $\delta / \mathrm{ppm}): 8.35(1 \mathrm{H}, \mathrm{s}$, arom $\mathrm{H}), 7.78-7.88(2 \mathrm{H}, \mathrm{m}, \operatorname{arom~} \mathrm{H}), 7.40$ $(1 \mathrm{H}, \mathrm{t}, J=8.0 \mathrm{~Hz}$, arom $\mathrm{H}), 4.68\left(2 \mathrm{H}, \mathrm{s},-\mathrm{CH}_{2}\right) ; \mathrm{MS}(\mathrm{ESI}): \mathrm{m} / z$ $233.12\left[\mathrm{M}^{+\bullet}+\mathrm{H},{ }^{79} \mathrm{Br}^{35} \mathrm{Cl}\right], 235.1\left[\mathrm{M}^{+\bullet}+\mathrm{H}+2,{ }^{79} \mathrm{Br}^{37} \mathrm{Cl}\right.$ or ${ }^{81} \mathrm{Br}$ $\left.{ }^{35} \mathrm{Cl}\right], 237.20\left[\mathrm{M}^{+\bullet}+\mathrm{H}+4,{ }^{81} \mathrm{Br},{ }^{37} \mathrm{Cl}\right]$.

4.5.9. 2-Bromo-1-(4-chlorophenyl)ethanone (2i). Off-white solid, yield: $92 \%$, m.p. $94-96^{\circ} \mathrm{C}$. FT-IR $\left(\mathrm{KBr}, \mathrm{cm}^{-1}\right) 3000.9$, 2947.9, 1689.8, 1625.5, 1384.8, 1267.5, 853.3, 679.8, 564.8. ${ }^{1} \mathrm{H}$ NMR $\left(400 \mathrm{MHz}, \mathrm{CDCl}_{3}, \delta / \mathrm{ppm}\right): 8.12(2 \mathrm{H}, \mathrm{d}, J=8.0 \mathrm{~Hz}$, arom $\mathrm{H}), 7.72(2 \mathrm{H}, \mathrm{d}, J=8.0 \mathrm{~Hz}$, arom $\mathrm{H}), 4.52\left(2 \mathrm{H}, \mathrm{s},-\mathrm{CH}_{2}\right)$; MS (ESI): $m / z 233.01\left[\mathrm{M}^{+\bullet}+\mathrm{H},{ }^{79} \mathrm{Br}^{35} \mathrm{Cl}\right], 234.90\left[\mathrm{M}^{+\bullet}+\mathrm{H}+2\right.$, ${ }^{79} \mathrm{Br}{ }^{37} \mathrm{Cl}$ or $\left.{ }^{81} \mathrm{Br}{ }^{35} \mathrm{Cl}\right], 237.00\left[\mathrm{M}^{+\bullet}+\mathrm{H}+4,{ }^{81} \mathrm{Br},{ }^{37} \mathrm{Cl}\right]$.

4.5.10. 2-Bromo-1-(4-bromophenyl)ethanone (2j). Off-white

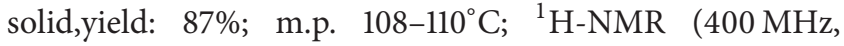
$\left.\mathrm{CDCl}_{3}, \delta / \mathrm{ppm}\right): 7.90(2 \mathrm{H}, \mathrm{d}, J=7.6 \mathrm{~Hz}$, arom H), $7.64(2 \mathrm{H}$, $\mathrm{d}, J=7.2 \mathrm{~Hz}$, arom $\mathrm{H}), 4.48\left(2 \mathrm{H}, \mathrm{s},-\mathrm{CH}_{2}\right) ; \mathrm{MS}(\mathrm{ESI}): \mathrm{m} / z$ $278.1\left[\mathrm{M}^{+\bullet}+\mathrm{H}, 2{ }^{79} \mathrm{Br}\right], 279.88\left[\mathrm{M}^{+\bullet}+\mathrm{H}+2,{ }^{79} \mathrm{Br}{ }^{81} \mathrm{Br}\right], 282.02$ $\left[\mathrm{M}^{+\bullet}+\mathrm{H}+4,2{ }^{81} \mathrm{Br}\right]$.

4.5.11. 2-Bromo-1-(4-methoxyphenyl)ethanone (2k). Offwhite solid, yield: $72 \%$; m.p. 70-72\%; FT-IR $\left(\mathrm{KBr}, \mathrm{cm}^{-1}\right)$ : 3098, 2938.2, 1688.8, 1600, 1509.1, 1326.2, 1263.7, 1021.4, 817.8, 
TABLE 7: Nuclear bromination of various aralkyl ketones containing high activating groups ${ }^{\mathrm{a}}$.

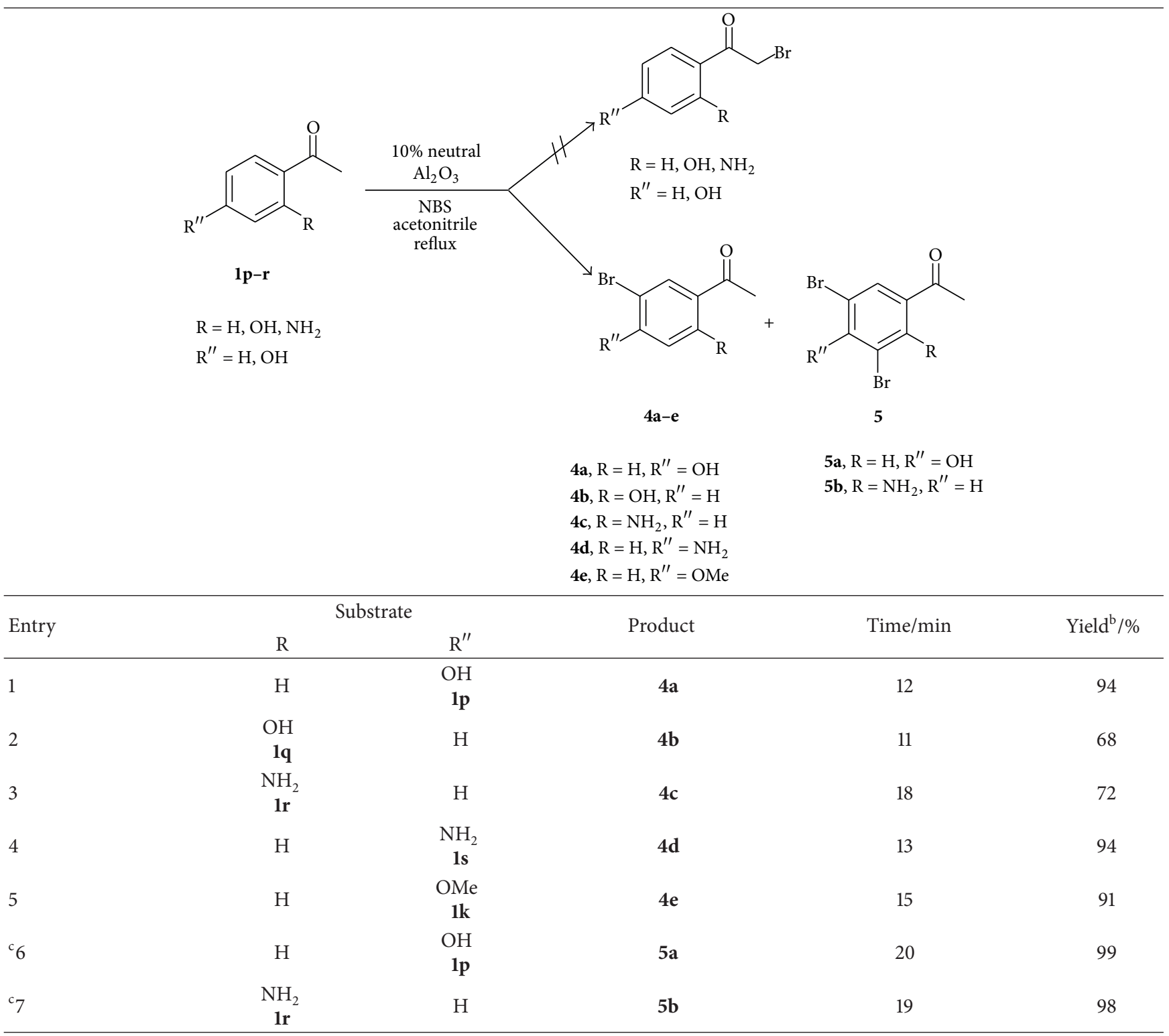

${ }^{\mathrm{a}}$ Reaction conditions: aralkyl ketone(s) $\mathbf{1 p - r}(10 \mathrm{mmol}), \mathrm{N}$-bromosuccinimide $(12 \mathrm{mmol})$, and $10 \%(\mathrm{w} / \mathrm{w})$ neutral $\mathrm{Al}_{2} \mathrm{O}_{3}$ in acetonitrile $(20 \mathrm{~mL})$ at reflux temperature.

${ }^{\mathrm{b}}$ Isolated yield.

${ }^{c} 22 \mathrm{mmol}$ of NBS was utilized.

687.3, 557.8; ${ }^{1} \mathrm{H}-\mathrm{NMR}\left(400 \mathrm{MHz}, \mathrm{CDCl}_{3}, \delta / \mathrm{ppm}\right): 7.95(2 \mathrm{H}$, $\mathrm{d}, J=7.4 \mathrm{~Hz}$, arom $\mathrm{H}), 6.95(2 \mathrm{H}, \mathrm{d}, J=7.4 \mathrm{~Hz}$, arom $\mathrm{H})$, $4.40\left(2 \mathrm{H}, \mathrm{s},-\mathrm{CH}_{2}\right), 3.90\left(3 \mathrm{H}, \mathrm{s},-\mathrm{CH}_{3}\right)$. MS (ESI) $m / z 229.0$ $\left[\mathrm{M}^{+\bullet}+\mathrm{H},{ }^{79} \mathrm{Br}\right], 231.01\left[\mathrm{M}^{+\bullet}+\mathrm{H}+2,{ }^{81} \mathrm{Br}\right]$.

4.5.12. 2-Bromo-1-(3-nitrophenyl)ethanone (2l). Yellowish solid, yield: 41\%; m.p. 93-96 C; FT-IR $\left(\mathrm{KBr}, \mathrm{cm}^{-1}\right)$ : 3049, 2947, 1669, 1605.5, 1489.4, 1159.5, 929.6, 853.1, 679.3, 564.5; ${ }^{1} \mathrm{H}-\mathrm{NMR}\left(400 \mathrm{MHz}, \mathrm{CDCl}_{3}, \delta / \mathrm{ppm}\right): 8.70(1 \mathrm{H}, \mathrm{s}$, arom $\mathrm{H})$, 8.35-8.55 (2H, m, arom $\mathrm{H}), 7.80-7.90(1 \mathrm{H}, \mathrm{m}$, arom $\mathrm{H}), 4.40$ $\left(2 \mathrm{H}, \mathrm{s},-\mathrm{CH}_{2}\right)$; MS (ESI): $m / z 244.05\left[\mathrm{M}^{+\bullet}+\mathrm{H},{ }^{79} \mathrm{Br}\right], 246.12$ $\left[\mathrm{M}^{+\bullet}+\mathrm{H}+2,{ }^{81} \mathrm{Br}\right]$.
4.5.13. 2-Bromo-1-(4-nitrophenyl)ethanone (2m). Yellowish solid, yield: 49\%; m.p. 99-102 ${ }^{\circ}$ C; FT-IR $\left(\mathrm{KBr}, \mathrm{cm}^{-1}\right) 3088$, 2992, 1690, 1523, 1347, 1195, 813.2, 729, 618, 490; ${ }^{1} \mathrm{H}-\mathrm{NMR}$ (400 MHz, $\left.\mathrm{CDCl}_{3}, \delta / \mathrm{ppm}\right): 8.21(2 \mathrm{H}, \mathrm{d}, J=7.2 \mathrm{~Hz}$, arom H), $8.61(2 \mathrm{H}, \mathrm{d}, J=7.2 \mathrm{~Hz}$, arom $\mathrm{H}), 4.41\left(2 \mathrm{H}, \mathrm{s},-\mathrm{CH}_{2}\right)$; MS (ESI): $m / z 244.1\left[\mathrm{M}^{+\bullet}+\mathrm{H},{ }^{79} \mathrm{Br}\right], 245.97\left[\mathrm{M}^{+\bullet}+\mathrm{H}+2,{ }^{81} \mathrm{Br}\right]$.

4.5.14. 2-Bromo-1-(naphthalen-1-yl)ethanone (2n). Brownish liquid, yield: $84 \%$; b.p. $348.5^{\circ} \mathrm{C}$; FT-IR $\left(\mathrm{KBr}, \mathrm{cm}^{-1}\right)$ : 3049.9 , 2948, 1689.8, 1625.4, 1469.3, 1174.6, 1126.9, 1029.5, 853.3, 811.6, 564.7; ${ }^{1} \mathrm{H}-\mathrm{NMR}\left(400 \mathrm{MHz}, \mathrm{CDCl}_{3}, \delta / \mathrm{ppm}\right): 8.75(1 \mathrm{H}, \mathrm{d}, J=$ $7.2 \mathrm{~Hz}$, arom $\mathrm{H}), 7.95-8.19(4 \mathrm{H}, \mathrm{m}$, arom $\mathrm{H}), 7.65-7.75(2 \mathrm{H}, \mathrm{m}$, 


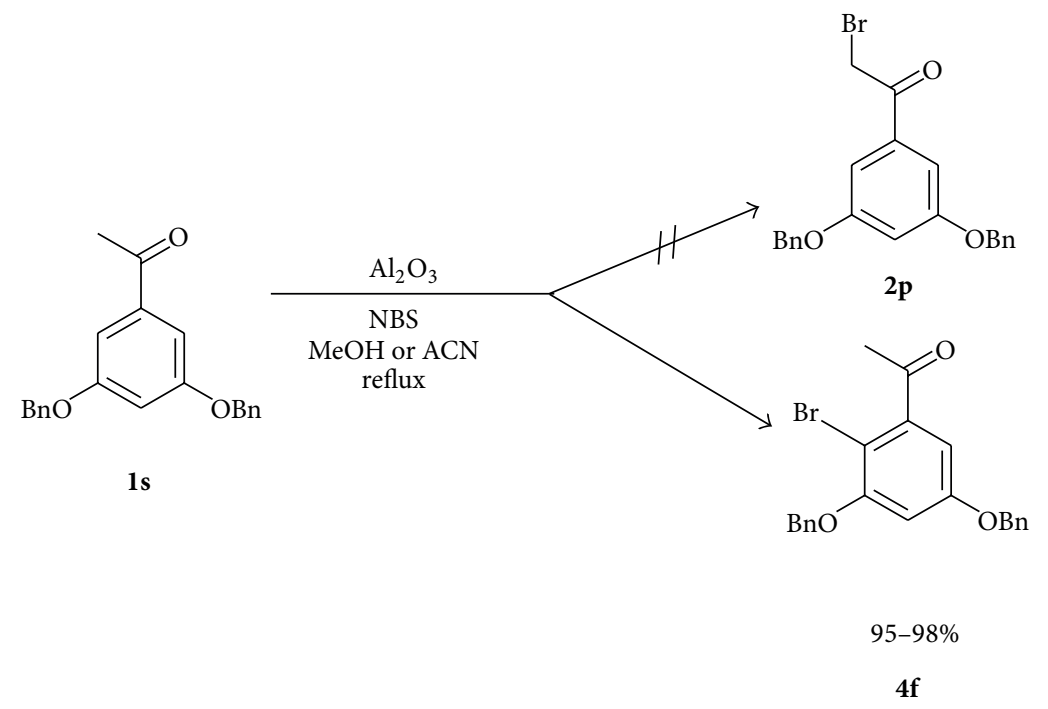

SCHEME 4: Nuclear bromination of 3,5-dibenzyloxy acetophenone (1s).

arom $\mathrm{H}), 4.70\left(2 \mathrm{H}, \mathrm{s},-\mathrm{CH}_{2}\right)$; MS (ESI): $m / z 249.0\left[\mathrm{M}^{+\bullet}+\mathrm{H}\right.$, $\left.{ }^{79} \mathrm{Br}\right], 251.1\left[\mathrm{M}^{+\bullet}+\mathrm{H}+2,{ }^{81} \mathrm{Br}\right]$.

4.5.15. 2-Bromo-1-(naphthalen-2-yl)ethanone (2o). Pale yellowish solid, yield: $91 \%$; m.p. $81-83^{\circ} \mathrm{C}$; FT-IR $\left(\mathrm{KBr}, \mathrm{cm}^{-1}\right)$ : 3088.2, 2997.4, 1702.4, 1610.2, 1434.7, 1199.8, 1082.9, 873.4, 818.2, 739.3, 618.8; ${ }^{1} \mathrm{H}-\mathrm{NMR}\left(400 \mathrm{MHz}, \mathrm{CDCl}_{3}, \delta / \mathrm{ppm}\right): 8.80$ $(1 \mathrm{H}, \mathrm{d}, J=7.6 \mathrm{~Hz}$, arom H), 7.95-8.19 $(4 \mathrm{H}, \mathrm{m}$, arom H), 7.60$7.78(2 \mathrm{H}, \mathrm{m}$, arom $\mathrm{H}), 4.30\left(2 \mathrm{H}, \mathrm{s},-\mathrm{CH}_{2}\right)$; MS (ESI): $m / z 249.1$ $\left[\mathrm{M}^{+\bullet}+\mathrm{H},{ }^{79} \mathrm{Br}\right], 251.05\left[\mathrm{M}^{+\bullet}+\mathrm{H}+2,{ }^{81} \mathrm{Br}\right]$.

4.5.16. 2,2-Dibromo-1-phenylethanone (3a). Colorless liquid, yield: $8-10 \%$; ${ }^{1} \mathrm{H}-\mathrm{NMR}\left(400 \mathrm{MHz}, \mathrm{CDCl}_{3}, \delta / \mathrm{ppm}\right)$ : $8.1-8.15$ $(2 \mathrm{H}, \mathrm{m}$, arom $\mathrm{H}), 7.51-7.81(3 \mathrm{H}, \mathrm{m}$, arom $\mathrm{H}), 6.60(1 \mathrm{H}, \mathrm{s},-\mathrm{CH})$; MS (ESI): $m / z 277.03\left[\mathrm{M}^{+\bullet}+\mathrm{H}, 2{ }^{79} \mathrm{Br}\right], 278.920\left[\mathrm{M}^{+\bullet}+\mathrm{H}+2\right.$, $\left.{ }^{79} \mathrm{Br},{ }^{81} \mathrm{Br}\right], 281.01\left[\mathrm{M}^{+\bullet}+\mathrm{H}+4,{ }^{81} \mathrm{Br}\right]$.

4.5.17. 1-(3-Bromo-4-hydroxyphenyl)ethanone (4a). Offwhite solid, yield: $94 \%$; ${ }^{1} \mathrm{H}-\mathrm{NMR}\left(400 \mathrm{MHz}, \mathrm{CDCl}_{3}, \delta / \mathrm{ppm}\right)$ : $8.18(1 \mathrm{H}, \mathrm{s}$, arom $\mathrm{H}), 7.95(1 \mathrm{H}, \mathrm{d}, J=7.2 \mathrm{~Hz}$, arom $\mathrm{H}), 7.22(1 \mathrm{H}$, $\mathrm{d}, J=7.2 \mathrm{~Hz}$, arom H), $5.42(1 \mathrm{H}, \mathrm{s}, \mathrm{OH}), 2.58\left(3 \mathrm{H}, \mathrm{s},-\mathrm{CH}_{3}\right)$; MS (ESI): $m / z 215.1\left[\mathrm{M}^{+\bullet}+\mathrm{H},{ }^{79} \mathrm{Br}\right], 217.08\left[\mathrm{M}^{+\bullet}+\mathrm{H}+2,{ }^{81} \mathrm{Br}\right]$.

4.5.18. 1-(5-Bromo-2-hydroxyphenyl)ethanone (4b). Offwhite solid, yield: $68 \%$; m.p. $43-45^{\circ} \mathrm{C}$; ${ }^{1} \mathrm{H}-\mathrm{NMR}(400 \mathrm{MHz}$, $\left.\mathrm{CDCl}_{3}, \delta / \mathrm{ppm}\right): 12.10(1 \mathrm{H}, \mathrm{s},-\mathrm{OH}), 8.2(1 \mathrm{H}, \mathrm{s}$, arom $\mathrm{H}), 8.02$ $(1 \mathrm{H}, \mathrm{d}, J=7.2 \mathrm{~Hz}$, arom $\mathrm{H}), 7.22(1 \mathrm{H}, \mathrm{d}, J=7.6 \mathrm{~Hz}$, arom $\mathrm{H})$, $2.62\left(3 \mathrm{H}, \mathrm{s},-\mathrm{CH}_{3}\right)$; MS (ESI): $m / z 215.21\left[\mathrm{M}^{+\bullet}+\mathrm{H},{ }^{79} \mathrm{Br}\right]$, $216.94\left[\mathrm{M}^{+\bullet}+\mathrm{H}+2,{ }^{81} \mathrm{Br}\right]$

4.5.19. 1-(2-Amino-5-bromophenyl)ethanone (4c). Off-white solid, yield: $72 \%$; m.p. $83-85^{\circ} \mathrm{C}$; ${ }^{1} \mathrm{H}-\mathrm{NMR}\left(400 \mathrm{MHz}, \mathrm{CDCl}_{3}\right.$, $\delta / \mathrm{ppm}): 8.03(1 \mathrm{H}, \mathrm{s}$, arom $\mathrm{H}), 7.58(1 \mathrm{H}, \mathrm{d}, J=6.8 \mathrm{~Hz}$, arom $\mathrm{H}), 7.13(1 \mathrm{H}, \mathrm{d}, J=7.2 \mathrm{~Hz}$, arom $\mathrm{H}), 6.42\left(2 \mathrm{H}, \mathrm{s},-\mathrm{NH}_{2}\right), 2.7$ $\left(3 \mathrm{H}, \mathrm{s},-\mathrm{CH}_{3}\right)$; MS (ESI): $m / z 214.09\left[\mathrm{M}^{+\bullet}+\mathrm{H},{ }^{79} \mathrm{Br}\right], 215.89$ $\left[\mathrm{M}^{+\bullet}+\mathrm{H}+2,{ }^{81} \mathrm{Br}\right]$.
4.5.20. 1-(4-Amino-5-bromophenyl)ethanone (4d). Off-white solid, yield: 94\%; m.p. $155-157^{\circ} \mathrm{C}$; ${ }^{1} \mathrm{H}-\mathrm{NMR}(400 \mathrm{MHz}$, $\left.\mathrm{CDCl}_{3}, \delta / \mathrm{ppm}\right): 8.15(1 \mathrm{H}, \mathrm{s}$, arom $\mathrm{H}) ; 7.82(1 \mathrm{H}, \mathrm{d}, J=7.2 \mathrm{~Hz}$, arom $\mathrm{H}), 6.98(1 \mathrm{H}, \mathrm{d}, J=7.2 \mathrm{~Hz}$, arom $\mathrm{H}), 6.23\left(2 \mathrm{H}, \mathrm{bs},-\mathrm{NH}_{2}\right)$, $2.7\left(3 \mathrm{H}, \mathrm{s},-\mathrm{CH}_{3}\right)$; MS (ESI): $m / z 214.1\left[\mathrm{M}^{+\bullet}+\mathrm{H},{ }^{79} \mathrm{Br}\right], 215.89$ $\left[\mathrm{M}^{+\bullet}+\mathrm{H}+2,{ }^{81} \mathrm{Br}\right]$.

4.5.21. 1-(3-Bromo-4-methoxyphenyl)ethanone (4e). Offwhite solid, yield: $91 \%$; m.p. $70-72^{\circ} \mathrm{C}$; FT-IR $\left(\mathrm{KBr}, \mathrm{cm}^{-1}\right)$ : 3098, 2938.2, 2840, 1688.8, 1600, 1509.1, 1326.2, 1263.7, 1207.5, 1168.3, 1021.4, 940.8, 817.8, 687.3, 580.1, 557.8; ${ }^{1} \mathrm{H}-\mathrm{NMR}$ (400 MHz, $\left.\mathrm{CDCl}_{3}, \delta / \mathrm{ppm}\right): 8.1(1 \mathrm{H}, \mathrm{s}$, arom H), $7.83(1 \mathrm{H}, \mathrm{d}, J$ $=7.6 \mathrm{~Hz}, \operatorname{arom~H}), 6.95(1 \mathrm{H}, \mathrm{d}, J=7.2 \mathrm{~Hz}, \operatorname{arom~H}), 4.01(3 \mathrm{H}$, $\left.\mathrm{s},-\mathrm{CH}_{3}\right), 2.71\left(3 \mathrm{H}, \mathrm{s},-\mathrm{CH}_{3}\right)$; MS (ESI) $m / z: 229.0\left[\mathrm{M}^{+\bullet}+\mathrm{H}\right.$, $\left.{ }^{79} \mathrm{Br}\right], 231.06\left[\mathrm{M}^{+\bullet}+\mathrm{H}+2,{ }^{81} \mathrm{Br}\right]$.

4.5.22. 1-(3,5-Bis(benzyloxy)-2-bromophenyl)ethanone (4f). Off-white solid, yield: 98\%; m.p. $83-85^{\circ} \mathrm{C}$; ${ }^{1} \mathrm{H}-\mathrm{NMR}$ (400 $\left.\mathrm{MHz}, \mathrm{CDCl}_{3}, \delta / \mathrm{ppm}\right): 7.45-7.25(10 \mathrm{H}, \mathrm{m}$, arom H), 7.59 $(1 \mathrm{H}, \mathrm{s}$, arom $\mathrm{H}), 7.68(1 \mathrm{H}, \mathrm{s}$, arom $\mathrm{H}), 5.02\left(2 \mathrm{H}, \mathrm{s},-\mathrm{CH}_{2}\right)$, $5.14\left(2 \mathrm{H}, \mathrm{s},-\mathrm{CH}_{2}\right), 2.6\left(3 \mathrm{H}, \mathrm{s},-\mathrm{CH}_{3}\right) ; \mathrm{MS}(\mathrm{ESI}): m / z 411.00$ $\left[\mathrm{M}^{+\bullet}+\mathrm{H},{ }^{79} \mathrm{Br}\right], 412.93\left[\mathrm{M}^{+\bullet}+\mathrm{H}+2,{ }^{81} \mathrm{Br}\right]$.

4.5.23. 1-(3,5-Dibromo-4-hydroxyphenyl)ethanone (5a). Offwhite solid, yield: $99 \%$; m.p. $184-188^{\circ} \mathrm{C} ;{ }^{1} \mathrm{H}-\mathrm{NMR}(400 \mathrm{MHz}$, $\left.\mathrm{CDCl}_{3}, \delta / \mathrm{ppm}\right): 9.86(1 \mathrm{H}, \mathrm{s},-\mathrm{OH}), 8.10(2 \mathrm{H}, \mathrm{s}$, arom $\mathrm{H}), 2.60$ $\left(3 \mathrm{H}, \mathrm{s},-\mathrm{CH}_{3}\right)$; MS (ESI): $m / z 293.01\left[\mathrm{M}^{+\bullet}+\mathrm{H}, 2^{79} \mathrm{Br}\right], 294.89$ $\left[\mathrm{M}^{+\bullet}+\mathrm{H}+2,{ }^{79} \mathrm{Br}^{81} \mathrm{Br}\right], 297.09\left[\mathrm{M}^{+\bullet}+\mathrm{H}+4,2{ }^{81} \mathrm{Br}\right]$.

4.5.24. 1-(2-Amino-3,5-dibromophenyl)ethanone (5b). Offwhite solid, yield: $98 \%$; m.p. $121-123^{\circ} \mathrm{C}$; ${ }^{1} \mathrm{H}-\mathrm{NMR}(400 \mathrm{MHz}$, $\left.\mathrm{CDCl}_{3}, \delta / \mathrm{ppm}\right): 7.81(1 \mathrm{H}, \mathrm{s}$, arom $\mathrm{H}), 7.69(1 \mathrm{H}, \mathrm{s}$, arom $\mathrm{H})$, $6.82\left(2 \mathrm{H}\right.$, bs, $\left.-\mathrm{NH}_{2}\right), 2.59\left(3 \mathrm{H}, \mathrm{s},-\mathrm{CH}_{3}\right) ; \mathrm{MS}(\mathrm{ESI}): \mathrm{m} / z$ 293.01 $\left[\mathrm{M}^{+\bullet}+\mathrm{H}, 2{ }^{79} \mathrm{Br}\right], 294.89\left[\mathrm{M}^{+\bullet}+\mathrm{H}+2,{ }^{79} \mathrm{Br}{ }^{81} \mathrm{Br}\right], 297.1$ $\left[\mathrm{M}^{+\bullet}+\mathrm{H}+4,2^{81} \mathrm{Br}\right]$. 


\section{Conflict of Interests}

The authors declare that there is no conflict of interests regarding the publication of this paper.

\section{Acknowledgment}

This work has been supported financially by the Council of Scientific and Industrial Research (CSIR), New Delhi, Government of India through a major research Project (no. 01 (2391)/10/EMR-II).

\section{References}

[1] R. C. Larock, Comprehensive Organic Transformations, WileyVCH, New York, NY, USA, 2nd edition, 1999.

[2] A. W. Erian, S. M. Sherif, and H. M. Gaber, "The chemistry of $\alpha$-haloketones and their utility in heterocyclic synthesis," Molecules, vol. 8, no. 11, pp. 793-865, 2003.

[3] C. Christophersen, "Secondary metabolites from marine bryozoans. A review," Acta Chemica Scandinavica B, vol. 39, no. 7, pp. 517-529, 1985.

[4] M. B. Smith and J. March, Advanced Organic Chemistry, Reactions, Mechanisms and Structure, John Wiley \& Sons, New Jersey, NJ, USA, 6th edition, 2006.

[5] L. C. King and G. K. Ostrum, "Selective bromination with copper(II) bromide," Journal of Organic Chemistry, vol. 29, no. 12, pp. 3459-3461, 1964.

[6] S. J. Pasaribu and L. K. Williams, "Selective bromination of substituted acetophenones with dioxan dibromide," Australian Journal of Chemistry, vol. 26, no. 6, pp. 1327-1331, 1973.

[7] S. Kajigaeshi, T. Kakinami, T. Okamoto, and S. Fujisaki, "Synthesis of bromoacetyl derivatives by use of Tetrabutylammonium Tribromide," Bulletin of the Chemical Society of Japan, vol. 60, no. 3, pp. 1159-1160, 1987.

[8] J. Ju, Y. J. Li, J. R. Gao et al., "High selectively oxidative bromination of toluene derivatives by the $\mathrm{H}_{2} \mathrm{O}_{2}-\mathrm{HBr}$ system," Chinese Chemical Letters, vol. 22, no. 4, pp. 382-384, 2011.

[9] A. T. Khan, M. A. Ali, P. Goswami, and L. H. Choudhury, "A mild and regioselective method for $\alpha$-bromination of $\beta$ keto esters and 1,3-diketones using bromodimethylsulfonium bromide (BDMS)," Journal of Organic Chemistry, vol. 71, no. 23, pp. 8961-8963, 2006.

[10] R. Hosseinzadeh, M. Tajbakhsh, M. Mohadjerani, and Z. Lasemi, "Ethylenebis(N-methylimidazolium) ditribromide (EBMIDTB): an efficient reagent for the monobromination of 1,3-diketones and $\beta$-ketoesters," Monatshefte fur Chemie, vol. 140, no. 1, pp. 57-60, 2009.

[11] G. F. Mendonça, H. C. Sindra, L. S. de Almeida, P. M. Esteves, and M. C. S. de Mattos, "Trihaloisocyanuric acids as convenient reagents for regioselective halogenation of $\beta$-dicarbonyl compounds," Tetrahedron Letters, vol. 50, no. 4, pp. 473-475, 2009.

[12] Y. Sarrafi, M. Sadatshahabi, and K. Alimohammadi, "A mild, simple and efficient method for selective $\alpha$-monobromination of 1,3-diketones and $\beta$-keto-esters using pyridinium bromochromate," Chinese Chemical Letters, vol. 20, no. 4, pp. 393396, 2009.

[13] A. K. MacHarla, R. C. Nappunni, M. R. Marri, S. Peraka, and N. Nama, "Oxidative bromination of ketones using ammonium bromide and oxone," Tetrahedron Letters, vol. 53, no. 2, pp. 191195, 2012.
[14] K. Tanemura, T. Suzuki, Y. Nishida, K. Satsumabayashi, and T. Horaguchi, "Halogenation of aromatic compounds by $\mathrm{N}$ chloro-, $N$-bromo- and $N$-iodosuccinimide," Chemistry Letters, vol. 32, no. 10, pp. 932-933, 2003.

[15] H. Schmid and P. Karrer, "Verbesserung und Erweiterung der Bromierungsmethode mit Brom-succinimid," Helvetica Chimica Acta, vol. 29, no. 3, pp. 573-581, 1946.

[16] H. M. Meshram, P. N. Reddy, P. Vishnu, K. Sadashiv, and J. S. Yadav, "A green approach for efficient $\alpha$-halogenation of $\beta$-dicarbonyl compounds and cyclic ketones using $N$ halosuccinimides in ionic liquids," Tetrahedron Letters, vol. 47, no. 6, pp. 991-995, 2006.

[17] S. S. Arbuj, S. B. Waghmode, and A. V. Ramaswamy, "Photochemical $\alpha$-bromination of ketones using $N$-bromo-succinimide: a simple, mild and efficient method," Tetrahedron Letters, vol. 48, no. 8, pp. 1411-1415, 2007.

[18] M. V. Adhikari and S. D. Samant, "Sonochemical bromination of acetophenones using p-toluenesulfonic acid- $N$-bromosuccinimide," Ultrasonics Sonochemistry, vol. 9, no. 2, pp. 107-111, 2002.

[19] I. Pravst, M. Zupan, and S. Stavber, "Halogenation of ketones with $N$-halosuccinimides under solvent-free reaction conditions," Tetrahedron, vol. 64, no. 22, pp. 5191-5199, 2008.

[20] D. Yang, Y. L. Yan, and B. Lui, "Mild $\alpha$-halogenation reactions of 1,3-dicarbonyl compounds catalyzed by Lewis acids," Journal of Organic Chemistry, vol. 67, no. 21, pp. 7429-7431, 2002.

[21] K. Tanemura, T. Suzuki, Y. Nishida, K. Satsumabayashi, and T. Horaguchi, "A mild and efficient procedure for $\alpha$-bromination of ketones using $N$-bromosuccinimide catalysed by ammonium acetate," Chemical Communications, vol. 10, no. 4, pp. 470-471, 2004.

[22] H. M. Meshram, P. N. Reddy, K. Sadashiv, and J. S. Yadav, "Amberlyst-15-promoted efficient 2-halogenation of 1,3-ketoesters and cyclic ketones using $N$-halosuccinimides," Tetrahedron Letters, vol. 46, no. 4, pp. 623-626, 2005.

[23] A. Rahman and S. B. Jonnalagadda, "Simple and efficient system for the $\alpha$-bromination of a $\beta$-ketoester by using $N$ bromosuccinimide in the presence of silicasupported $\mathrm{NaHCo3}$ as the heterogeneous catalyst: an environmentally benevolent approach," Synthetic Communications, vol. 42, no. 8, pp. 10911100, 2012.

[24] B. Das, K. Venkateswarlu, G. Mahender, and I. Mahender, "A simple and efficient method for $\alpha$-bromination of carbonyl compounds using $\mathrm{N}$-bromosuccinimide in the presence of silica-supported sodium hydrogen sulfate as a heterogeneous catalyst," Tetrahedron Letters, vol. 46, no. 17, pp. 3041-3044, 2005.

[25] H. Jin, Z. D. Huang, C. X. Kuang, and X. K. Wang, "Ironcatalyzed bromination of aryl azides by $N$-bromosuccinimide: efficient method for the synthesis of brominated aryl azides," Chinese Chemical Letters, vol. 22, no. 3, pp. 310-313, 2011.

[26] R. B. Mohan and N. C. Gangi Reddy, "Regioselective $\alpha$ bromination of aralkylketones using $\mathrm{N}$-bromosuccinimide in presence of montmorillonite k-10 clay: a simple and efficient method," Synthetic Communications, vol. 43, no. 19, pp. 26032614, 2013.

[27] R. B. Mohan, V. V. Ramana Kumar, N. C. Gangi Reddy, and S. Mahender Rao, "Silica gel catalyzed $\alpha$-bromination of ketones using $N$-bromosuccinimide: an easy and rapid method," Chinese Chemical Letters, vol. 25, no. 1, pp. 179-182, 2014. 
[28] J. Duan, L. H. Zhang, and W. R. Dolbier Jr., "A convenient new method for the bromination of deactivated aromatic compounds," Synlett, no. 8, pp. 1245-1246, 1999.

[29] P. Bovonsombat and E. McNelis, "Ring halogenations of polyalkylbenzenes with $N$-halosuccinimide and acidic catalysts," Synthesis, no. 2, pp. 237-241, 1993.

[30] J. Auerbach, S. A. Weissman, T. J. Blacklock, M. R. Angeles, and K. Hoogsteen, " $N$-bromosuccinimide/dibromodimethylhydantoin in aqueous base: a practical method for the bromination of activated benzoic acids," Tetrahedron Letters, vol. 34, no. 6, pp. 931-934, 1993.

[31] Y. Goldberg and H. Alper, "Electrophilic halogenation of aromatics and heteroaromatics with $N$-halosuccinimides in a solid/liquid system using an $\mathrm{H}^{+}$ion exchanger or ultrasonic irradiation," Journal of Molecular Catalysis, vol. 88, no. 3, pp. 377-383, 1994.

[32] V. Paul, A. Sudalai, T. Daniel, and K. V. Srinivasan, "Regioselective bromination of activated aromatic substrates with $\mathrm{N}$ bromosuccinimide over HZSM-5," Tetrahedron Letters, vol. 35, no. 38, pp. 7055-7056, 1994.

[33] K. Smith, Solids Supports and Catalysts in Organic Synthesis, Ellis Horwood, Chichester, UK, 1992.

[34] P. Laszlo, Preparative Chemistry Using Supported Reagents, Academic Press, London, UK, 1987.

[35] H. van Bekkum, E. M. Flanigen, and J. C. Jansen, Introduction to Zeolite Science and Practice, vol. 58 of Studies in Surface Science and Catalysis, 1991.

[36] H. Pines and W. O. Haag, "Alumina: catalyst and support. I: alumina, its intrinsic acidity and catalytic activity," Journal of the American Chemical Society, vol. 82, no. 10, pp. 2471-2483, 1960.

[37] R. J. Farrauto, K. E. Voss, and R. M. Heck, "Ceria-alumina oxidation catalyst," US Patent 5462907, 1995.

[38] A. Corado, A. Kiss, H. Knözinger, and H. D. Müller, "Catalytic isomerization of olefins on alumina. II: catalyst deactivation and its effects on the mechanism," Journal of Catalysis, vol. 37, no. 1, pp. 68-80, 1975.

[39] A. Tsuruoka, Y. Kaku, H. Kakinuma et al., "Synthesis and antifungal activity of novel thiazole-containing triazole antifungals. II: optically active ER-30346 and its derivatives," Chemical and Pharmaceutical Bulletin, vol. 46, no. 4, pp. 623-630, 1998. 

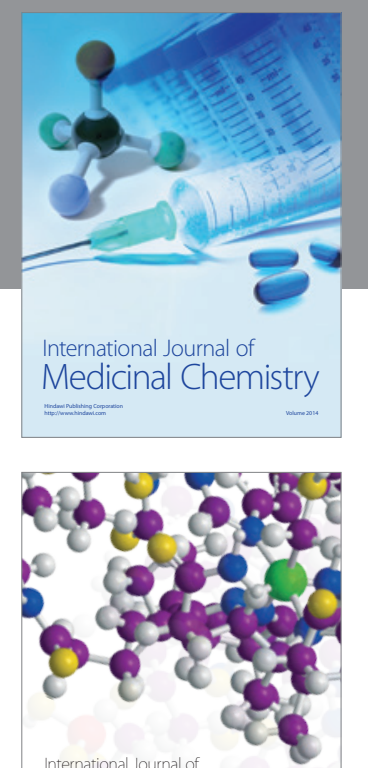

\section{Carbohydrate} Chemistry

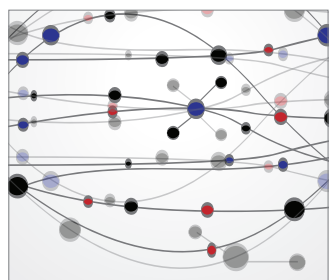

The Scientific World Journal
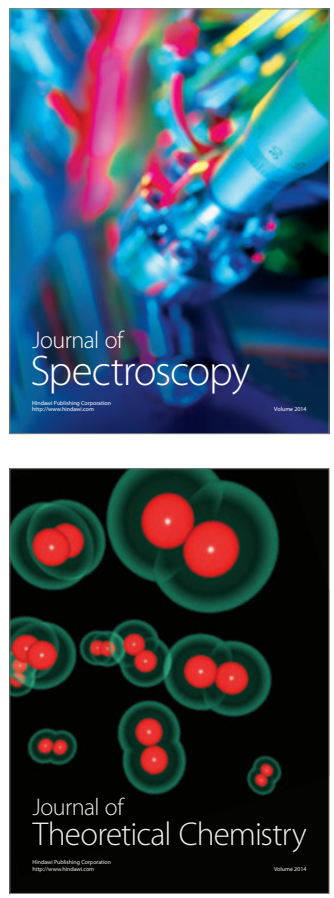
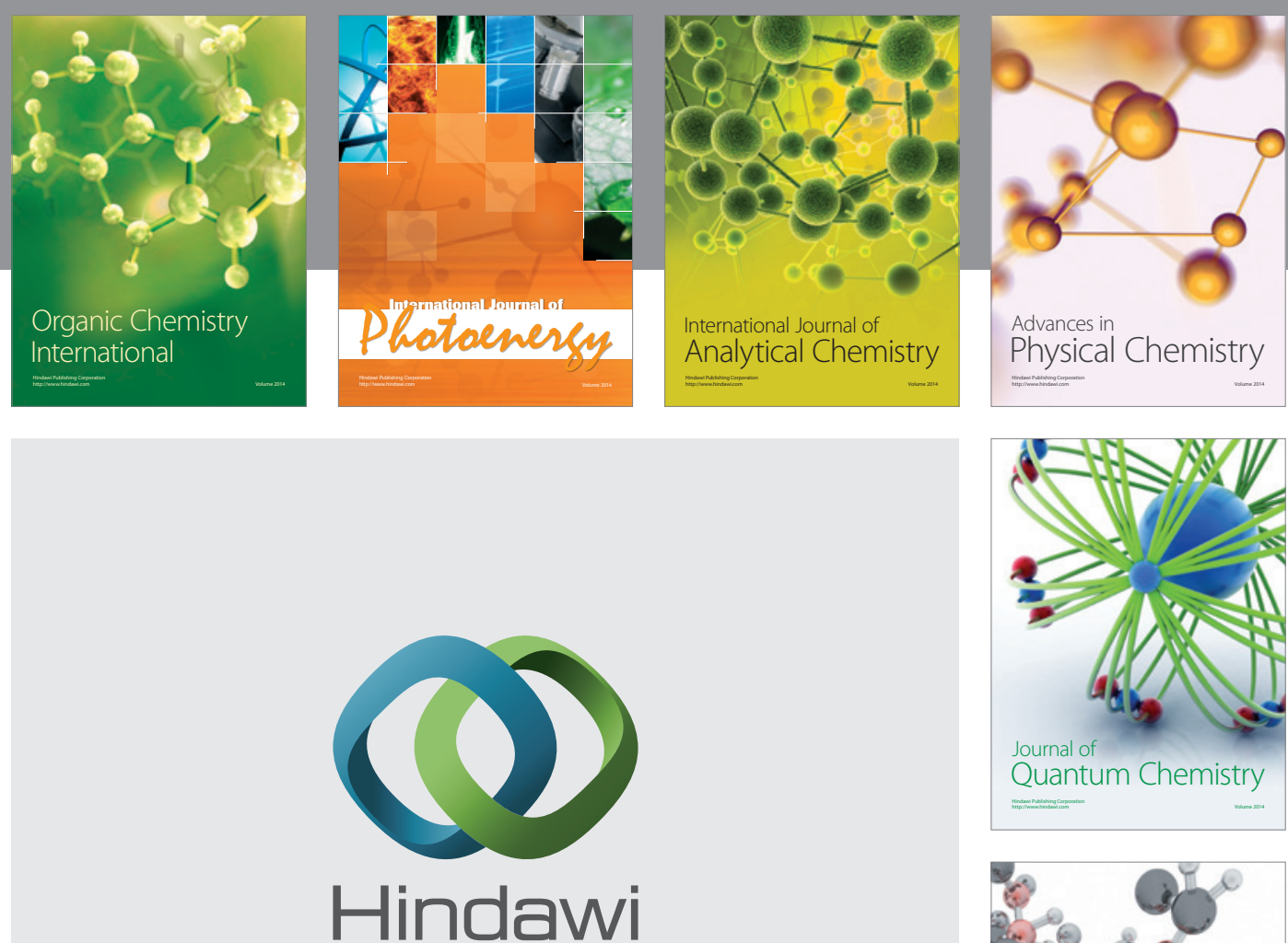

Submit your manuscripts at

http://www.hindawi.com

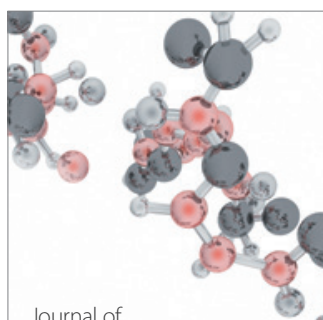

Analytical Methods

in Chemistry

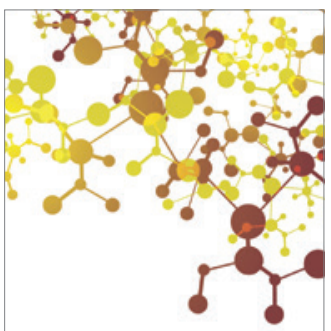

Journal of

Applied Chemistry

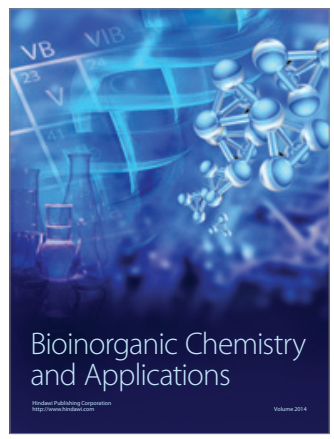

Inorganic Chemistry
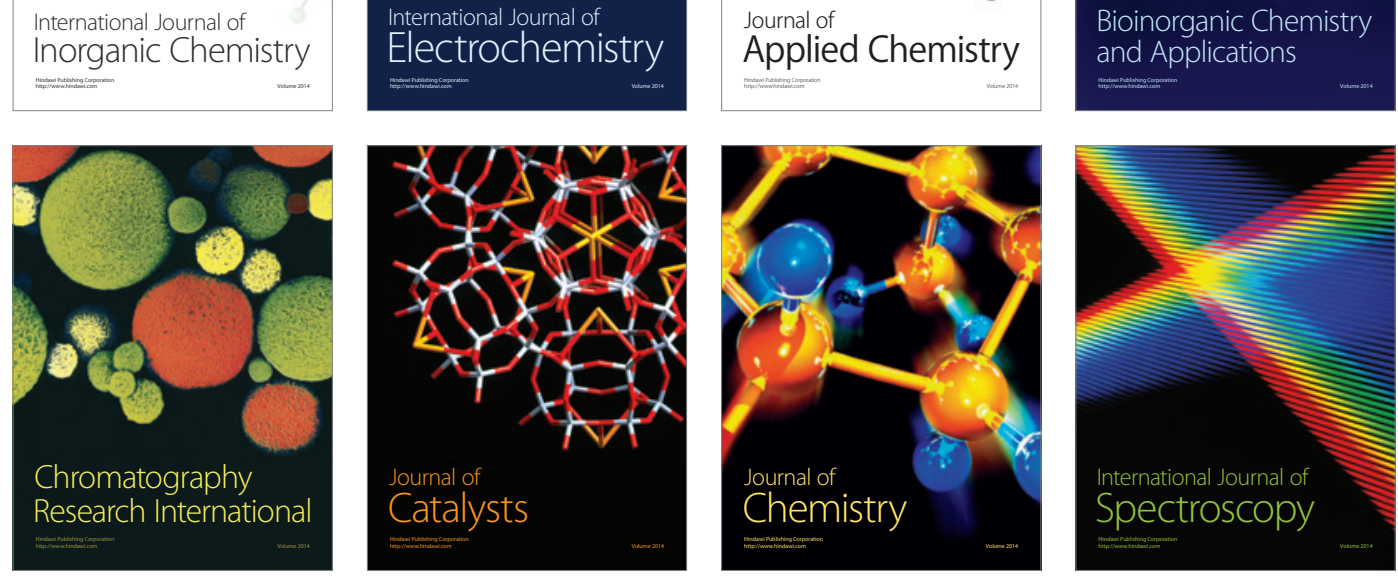